\title{
The Challenge of Technical and Vocational Training and Education in Rural Areas: the Case of South-Asia
}

\author{
Wolfgang Vollmann*
}

\begin{tabular}{r|l} 
Introduction \\
The subject of TVET in rural areas, especially in South Asia, is of \\
high importance in view of the large number of people living in \\
these areas, also because of huge numbers of adult illiterates in the \\
four countries concerned, probably more than 530 million illiterates \\
according to latest estimates (400 million in India, 60 million in \\
Bangladesh, 60 million Pakistan, and 12 million in Nepal).
\end{tabular}

Journal of Education and Research Vol. 2, 2010 
Enrol. Voc. GER

$\begin{array}{lll}\text { India } & 619303 & 0.4 \% \\ \text { Bangladesh } & 123746 & 0.5 \% \\ \text { Nepal } & 20546 & 0.5 \%\end{array}$

More recent data, 2006/7, published by the national statistical offices indicate that the rate has generally risen to $1 \%$ of the relevant age cohort.

A reportby Fernando (2005) confirms the dismally small number of TVET students: 140000 only in Bangladesh. In particular Fernando points to the small number of TVET/textile students: the six centres for textile training enrolled a mere 360 students only; in a country with thousands of textile factories !

Worse: in view of the growing numbers of primary school leavers and secondary education entry students, one could almost state that in absolute terms the numbers have further declined. Likewise the number of teachers for TVET remains also extremely small: in 2005, there were 40 teacher/students enrolled at Dhaka university, 40 at the Technical Teacher Training college, Dhaka, and 200 at the Bogra Vocational Teacher Training College.

\section{Education and TVET}

Several South-Asian countries have courageously initiated well-planned TVET programmes, but persistently strong cultural and social value patterns seem to discourage students from entering technical or vocational training, even in secondary schools. This is especially valid in rural areas where manual labour and training are widely considered of much lesser prestige than learning at the hands of books. Already one can notice here the strong impact of socio-cultural barriers.

In addition, there is the perceived inaction by both Governments, India and Bangladesh, failing to undertake the required PR work to better market TVET courses in rural areas.
The lack of political support seems to be based on political considerations by local politicians inclined to follow mainstream thinking and attitudes, avoiding to antagonize their political support groups or voter banks. It may be said, that promoting TVET would currently require a considerable political courage, defying the odds, and going against popular thinking and expectations.

By examining more closely, later, the impact of socio-cultural values that determine attitudes towards TVET, we will certainly gain a better insight into the workings of society and its needs in the development process. A proper understanding of these values and norms in rural areas would allow policy makers to address the issue, i.e. specific behaviour patterns, not as an obstacle but as an issue that need to be considered and dealt with in an objective, people-respecting manner.

At this point of the paper we should retain that the complex social conditions and attitudes in rural areas condition increasingly the prevailing unemployment or better under-employment, whereby people may "welcome" rising $\mathrm{PE}$ enrolments on the one hand and "oppose" manual education and training on the other hand, especially for girls (UNESCO, 2006, p 2; \& King, 2007, p. 26).

The huge number of unemployed or underemployed adults in rural areas is also a consequence of growing numbers of PE graduates trying to seek entry into secondary education, but fail to succeed. These are the new unemployed in rural areas.

TVET may have the potential, as a logical extension of basic education, to take people out of poverty; but the general under-employment and dismal educational situation in rural areas tell a different story. On the basis of recent data, it appears clearly that TVET faces a serious problem in South-Asia, where innovative and bold TVET strategies, targeting the rural populations would 
54 Wolfgang Vollmann

be welcome, but surely are not enough.

\section{TVET, an urban affair ?}

First of all we have to acknowledge that there are very few TVET opportunities available in rural areas. If ever there would be a TVET institution, most likely it would be situated in a nearby rural town. Given the socio-cultural conditions, many young women for example would find it difficult to travel to such a distant location (King, 2007, p. 27).

In general, TVET institutions are based in urban centres, attracting urban students, though in insufficient numbers, and offering exclusively urban skills and professions. In a report by Earl Fernando on TVET in Bangladesh (UNESCO/ Dhaka, 2005), all institutions listed are without exception situated in urban centres, many of them in Dhaka. It is surprising to see this largely city-focused organization of TVET, while 80 percent of the population live in rural areas.

What are the reasons which obstruct TVET progress in rural areas? In the light of the aforesaid, and before developing yet another "promising strategy", it would appear necessary to examine carefully the different factors and characteristics of the social, cultural and religious conditions which pre-determine professional needs and training.

\section{Traditional behaviour patterns}

The life of rural populations in South-Asia is still largely governed by century-old, complex traditional value systems having produced specific behaviour patterns, and which in all likelihood determine access to rural professional skills. A brief examination of the broad outlines of prevalent or visible behaviour patterns is likely to yield, through an evaluative analysis, reasons for better understanding the prevailing rigid professional pattern in rural areas, and why TVET is not yet succeeding there. "TVET is an area where values and attitudes towards TVET are clearly different from Western perceptions
(King, 2007, p. 26)".

Traditions actually cover a wide and complex variety of social behaviour patterns, where strict rules of kinship play a major role. It is by looking at kinship structures that we would be able to identify certain rules relating to the exercise of professional activities, as well as the place of women in rural communities. The most well known kinship practices can be found in current marriage traditions, where early and arranged marriages are largely practiced, but always according to strict kinship rules.

On the basis of inherited rules of social behaviour, most of the marriages are patrilocal (bride lives at in-law's place), and which is the case in most of South-Asia, exogamous in Hindu communities (but within the same caste) and endogamous in most of the Islamic communities. Another but rare practice is called "matrilocal" whereby the bridegroom stays with his in-laws; this concerns the Najar in Kerala, and some ethnic groups in Nepal .

Heritage, land or other property, is transmitted either following the patrilinear or matrilinear rules. Following customary law in Hindu communities, daughters in principle do not inherit anything; in Moslem communities daughters would be entitled to 50 percent of what the male inheritor (son) would receive.

The endogamous marriage practices prevalent in Pakistan and Bangladesh, and patrilinear kinship patterns, ensure that property remains largely within the family.

For example in Punjab of Pakistan it has been found that more than $50 \%$ of marriages occur amongst $1^{\text {st }}$ degree cousins, which would point to the intention to keep property, land, within the family.

In the case of patrilocal marriages and patrilinear inheritance in rural areas, young women tend to be strongly excluded or discouraged from work or learning a job or skill; the employment data for South-Asia indicate clearly that this is 
particularly the case in Pakistan, and to a lesser extent in India, Nepal and Bangladesh.

In particular it has been found that early marriages, on the basis of patrilocality and patrilinearity, tend to keep young women at home, and in pursuance of the age-old Purdah tradition they are expected to raise children and be a home provider. Women living in such rigid marital conditions are usually not showing much interest in any kind of job training, neither are they encouraged by their husband or his family

Surprisingly when looking at equivalent marriage practices in Southeast-Asia, we notice different behaviour patterns. For example in Thailand, Malaysia or Myanmar, marriage residence is either matrilocal or mixed, patri/matrilocal; this practice seems to provide young married women with more social opportunities to enter public life and therefore the job market. This is probably due to less pressure from the head of an extended family, who in some cases could even be a woman; this is especially relevant when matrilinear inheritance is practiced, giving women more economic bargaining power.

In the case of South-Asia, and in view of TVET possibilities, one has to retain the overwhelming role of traditional patriarchal behaviour patterns in terms of practices related to marriage, inheritance and residence. De facto these patterns do not favour the empowerment of young women, neither their entry into professional training or even the job market; even young men who would like to go for a different profession than their father, the currently prevailing rigid social traditions would prevent them from doing so.

It is however important to keep in mind that this tradition-minded behaviour, based on specific patrilinear kinship patterns and value systems, appears to those who practice and live it, absolutely essential for the survival of the family, the village and the community. Any innovation needs to build on this paradigm.
Transforming attitudes is a heavy task, and Hugues (Prospects 135, 2005, p. 260) puts it this way: "Nepal, has 23 million people, mostly in rural areas, with 2 Million children working in agriculture. It is estimated that $54 \%$ of children never complete primary education. An approach is needed that provides skills for work and could help transform attitudes". The question of transforming attitudes becomes complex as we have seen above, when traditional behaviour patterns, responding to a specific set of norms and values, "dictate" to young men and women, where they have to live, marry and work. In addition questions of linguistic and religious traditions add another complex set of behavioural attitudes and laws.

\section{Caste and class}

One of the biggest obstacles for TVET in rural areas, is that community traditions are governing specific jobs and skills, which are to be exercised by a special group of people of the community, caste or family. For example the son of fisherman is to be fisherman, son of carpenter to be carpenter, son of peasant to be peasant, son of weaver to be weaver, etc, etc. The transmission of a given profession from generation to generation, within strict family or caste, is a founding element of many societies in South-Asia.

In addition to the generational transmission of traditional professional skills, countries like India and Nepal, where Hinduism is still governing most of the socio-cultural relations in rural areas, are also confronted with castedefined behaviour. It implies that many trades/ professions, especially those involving manual work, belong to a well-defined sub-caste, and it would be almost impossible for a young member of such a professional sub-caste, to enter a different profession within sight of his community. He would run the danger of losing his social identity!

Caste defined behaviour also involves acceptance of the notion of perceived spiritual impurity and 
$56 \mid$ Wolfgang Vollmann

even pollution, when a member of a lower or very low caste accidentally touches other objects or working areas where higher caste members could consider of being "polluted", or having become "unclean", through indirect contact with a low caste. This behaviour still holds in large areas in rural India and Nepal.

We have to acknowledge therefore the existence of a very rigid local professional framework in rural areas which, in addition to traditional marriage practices, may bar the way to a broader concept of professional training and education.

It may be said that the current very low TVET enrolment data (less than $1 \%$ across South-Asia, except Sri Lanka), bespeak of the immense difficulty for national policy makers, despite numerous national plans, to make significant headway in terms of vocational training for young people. In particular young girls and women appear to suffer from being excluded from public life, learning and vocational training.

For example in Pakistan, where we have seen that in rural Punjab, $50 \%$ of marriages occur between first degree cousins, and against the backdrop of patrilocal and endogenous marriage practices, we also note very low TVET enrolments for adolescent girls. It is then not surprising that official Punjab strategies, targeting women's empowerment, failed from the outset, confronted by the opposition of a strong patriarchal, male dominated community. The situation is further aggravated by the fact that men themselves, due to their keeping women at home (tradition of Purdah!), do not feel particularly encouraged to learn new professions or skills. On the contrary, these rural men are to follow in the footsteps of their father or the dominating male figure of the community, for the sake of the survival of the community or large family.

We are obviously confronted with a complex social and cultural situation in rural areas: i) the ever present role of strong kinship ties, ii) traditional marriage patterns, often resulting in keeping women at home, iii) the power of religious, linguistic and ethnic values and beliefs, generating specific behaviours patterns, and finally, iv) the rigid and exclusive professional picture. All these elements have a direct bearing on the success or failure of EFA and TVET policies.

In the light of the above described social realities, we have to ask ourselves what strategies need to be proposed, tested and applied, by making sure that these "socio-cultural traditions", remain fully respected, as they are not going to disappear by a sudden magic stroke.

The currently prevailing UNESCO (and ILO for that matter) strategies for TVET pay little attention to these socio-cultural realities in rural areas, although some knowledge appears here and there, for example in King (2007) and the UNESCO/Kathmandu report 2006. In both publications the paralysing role of traditions, though ill defined, is acknowledged.

\section{New TVET strategies}

With respect to formal and city-based TVET, another important lesson points to the urgent need that reporting data should reflect the entire gamut of TVET practices and measurements. Current TVET data seem to ignore the immense volume of many private, low-key, informal skills training provided by NGOs, private business and local organizations.

i) The task would consist of reflecting these activities in concrete data;

ii) to up-grade low-key training and adapt it better to suit local needs and constraints;

iii) to develop a certifying system likely to reflect these local and informal initiatives.

We have on the one hand identified a rigid social behaviour pattern, and many exclusive manual labour professions, in all rural areas of South-Asia. On the other side of the coin, we have noted the current TVET approach which appears highly formalized, situated in urban centres (Fernando, 2005) and principally focusing on training for 
The Challenge of Technical and Vocational Training and Education in Rural Areas $\mid 57$

industrial and urban needs, defined by employers or other city-based ministerial bureaucrats.

The sheer number of people living in rural areas in South-Asia, most of them living below the poverty line of one Dollar a day, makes it highly urgent to look beyond the immediate success of primary education enrolments and literacy, and envisage to plan for an informal TVET, meeting real needs.

Based on the experiences of many local projects, like the CLCs, informal skills learning initiatives, any informal TVET strategy would consist of:

i) systematic identification of local rural needs;

ii) establishment of small-scale TVET centres in bigger villages, to train

- teachers for specific local skills (fishery, horticulture, agriculture);

- delivering first degree certificates;

iii) small TVET centres would maintain and develop a network of CLCs and other local village centres, delivering basic skills and literacy;

iv) small TVET centres could also contribute to upgrade, through appropriate training, hitherto caste and class-based professions.

\section{Conclusion}

The previous remarks point to the fact that current TVET policies are not meeting the identified challenges in the rural areas of South-Asia.

In response to a growing number of primary education graduates, the current secondary education system with its exclusive focus on general education, does not respond to the felt needs of young people. The large majority of adolescents is de facto left out, by not being provided either with the alternative technical or vocational training to enter the job market with relevant skills. The result is a mismatch between relatively small but city-based and formal TVET centres, and the vast number of young people in rural areas deprived of any access to skills training. The prevalence of specific traditional value systems and consequent rigid behaviour patterns, characterize life, and professional life, in the countryside. This situation demands that any TVET offer respect these local conditions. Hence a solution would consist of providing informal and flexible rural TVET, where local NGOs and other providers would negotiate socially acceptable training opportunities, keeping in mind a threefold objective:

- $\quad$ respect local attitudes and demands;

- develop quality TVET adapted to local needs;

- $\quad$ link-up with decentralized TVET centres to ensure basic certification.

\section{Bibliography}

Bailey, F. G. (1957). Caste and the economic frontier. Manchester: Manchester University Press.

Banerjee, S. (2008). Men, women, domestics; articulating middle-class identity in colonial Bengal. New Delhi: Oxford University Press.

Beteille, A. (1974). Studies in agrarian social structure. New Delhi: Oxford University Press.

Courbage, Y. \& Todd, E. (2007). Le rendez-vous des civilisations. Paris: Seuil.

UNESCO/Dhaka (2006). Project completion report on "Empowering adolescent girls to become the agent of social transformation, Phase II". Dhaka: UNESCO.

Dube, S. C. (1955). Indian village. London: Routledge and Kegan Paul.

Dube, S. C. (1974). Contemporary India and its modernization. Delhi: Vikas Publishing.

Education Watch/CAMPE (2007). Financing primary and secondary education in Bangladesh. Dhaka: CAMPE. 
58 Wolfgang Vollmann

Eisenstadt, S. N. (1967). Transformation of social, political and cultural orders in modernization. In R. Cohen and J. Middelton (Eds) Comparative Political Systems.

Fernando, E. (2005). Feasibility report on centre for R\&D of TVET. Kathmandu: UNESCO.

Hiebert, P. G. (1971). Konduru, structure and integration in a South-Indian village. Minneapolis: Minneapolis University Press.

Holy, L. (1976). Kingroups: Structural analysis and the Study of Behaviour. In Annual Review of Anthropology.

Hutton, J. H. (1961). Caste in India: Its nature, function and origin. Bombay: Oxford University Press.

King, K. (2007). The role of UNESCO in supporting and promoting TVET in the Asia-Pacific region. Paris: UNESCO.

Prospects $\mathrm{N}^{\circ} 135$ (2005). Orientating TVET for sustainable development. Geneva: UNEVOC and IBE.

Mehta, S. (1971). Social conflicts in a village community. New Delhi: Chand Publications.

Nehru, J. (1989). The Discovery of India. New Delhi: Oxford University Press.
Paranjpe, A. C. (1970). Caste, prejudice and the individual. Bombay: Lalvani Publications.

Prahalad, C. K. (2005). The Fortune at the bottom of the pyramid. Wharton School Publishing.

Sarkar, T (2001). Hindu wife, Hindu nation. New Delhi: Permanent Black Publisher.

Sen, A. (2006). The Argumentative Indian. London: Penguin.

Srinivas, M. N. (1962). Caste in Modern India. Bombay: Asia Publishing House.

Uberoi, P. (1993/2005). Family, kinship and marriage in India. New Delhi: Oxford University Press.

UNDP (2007/08). The Human Development Report. New York: Author.

UNESCO (2003). Empowering adolescent girls: Breaking the poverty cycle of women. Paris: Author.

UNESCO (2005). Community learning center: The Bangladesh Experience. Dhaka: Author.

UNESCO (2006). Technology-based vocational training for marginalized girls. Kathmandu: Author. 